\title{
Limestone quarries and cave protection
}

\author{
Szabolcs Leél-Őssy \\ Eötvös Loránd University, Budapest, Hungary \\ Email: leel-ossy.szabolcs@ttk.elte.hu
}

\begin{abstract}
It happened in Hungary several times that a limestone quarry opened the entrance of a new, unknown cave during its activity such as the case was in the Villány Mountains, in Budapest, and in Keselö, Naszály or Esztramos Hills. It is right that the natural caves are protected, but what is the solution in such cases? Closing the mine? Absolving the cave from protection? It is a difficult question. The real way: we must weigh. Which is more expensive? How valuable and unique is the cave? How big is the economic loss if we close the mine? And how serious is the harm if it is allowed to annihilate the value of nature, which is impossible to reproduce? Examples follow from Hungary.
\end{abstract}

Keywords - limestone quarries, hypogene caves, cave protection, economic interest, real consideration

\section{INTRODUCTION}

There are a lot of hypogene caves in Hungary. The hypogene caves have no natural entrances, because rising thermal spring dissolved these caves, often not reaching the surface. The limestone quarries open unknown cave sections many times. This happened, for instance, in the southernmost part of Hungary, near to the Croatian border, in the Villány Mountains (Leél-Össy in print), near to Beremend and Nagyharsány, as well as in Budapest, in Naszály Hill (near to Vác), or in Esztramos Hill (near to Aggtelek).

Without the limestone quarry activity, we would have never known these caves. However, the quarrying does not only open but also destroys the caves! The caves are a treasure of nature, which cannot be repeated. What can we do? I think we must weigh the facts. What is the value of the limestone that is indispensable for the building industry? What is the ideal value of the cave?

In Hungary, every natural cave (longer than $2 \mathrm{~m}$ ) has been protected since 1961. However, is the protection of the $5 \mathrm{~m}$ long cave without any precipitation more important than a big quarry which gives several thousand tons of basic material for the industry and where dozens of people are working? This is a difficult question!
If the continuation of the work in a limestone mine is prohibited after the discovery of a small cave, every quarry will hide what they have found and will annihilate the cave immediately. The honest solution is to examine if there is a chance to continue the mining activity and to protect the cave too. I made my standpoint on this topic several times in the last decade. One time I thought that it was more important to continue the mining activity, another time I said that the protection of the new cave was more important. There was a precedent when the quarry had to continue its activity only 50 m away from the cave...

\section{SOME PLACES IN HUNGARY WHERE A LIMESTONE QUARRY "DISCOVERED" A NEW CAVE}

\subsection{Beremend}

The Villány Mountains (built up from Mesozoic rocks) are south of the Mecsek Mountains. The southernmost part of these mountains is Beremend Hill, which is an independent low hill (lower than $50 \mathrm{~m}$ ) in the plain of the Drava river (the river forms the border between Hungary and Croatia). This hill is a geological (tectonic) block - like the other nearby block at Harkány (Csondor, 2021). However, the Harkány block does not rise above the surface: the thermal water of the famous medicinal bath comes across the $50 \mathrm{~m}$ deep artificial 
well. The Villány block is built up from Triassic limestone, and the block of Beremend is built up from very clean Middle Cretaceous limestone: the thick shell of Requienia is visible on the wall in the Beremend Crystal Cave.

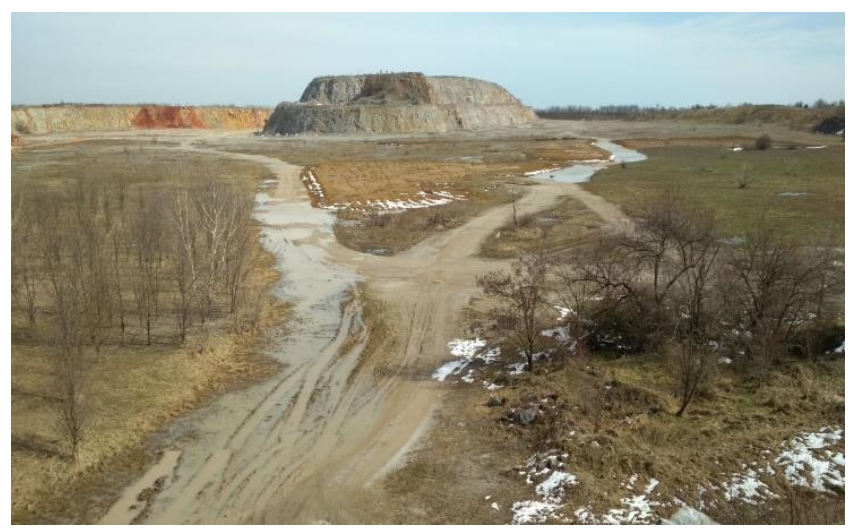

Figure 1. View of Beremend Quarry with protected area which contains a crystal cave. Photo: András Hegedüs

The quarry, which supplies the basic material for a cement plant near Beremend village, ,ate" the bigger part of the small hill during the decades by now. The mine here found and annihilated more than a dozen smaller-bigger caves in the $20^{\text {th }}$ century (Vigassy et al 2010).

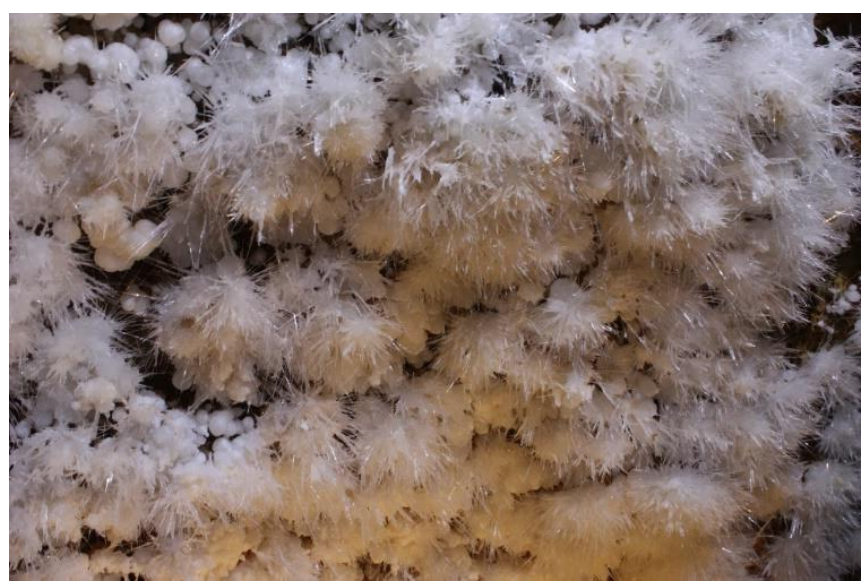

Figure 2. Popcorn and aragonite needles in Beremend Crystal Cave. Photo: András Hegedüs

The mining opened a small mouth of a new cave in the middle of the northern wing of the mine (in a very unlucky place) in the autumn of 1984. The leader of the shift looked into the cave and saw it was a big cave with very rich white precipitations. He invited the officials of the Ministry of Nature Protection. They discovered a $850 \mathrm{~m}$ long cave on a $60 \times 40 \mathrm{~m}$ area (Takács-Bolner, 2003a). The absolute vertical difference in the cave is $53 \mathrm{~m}$. (I was in the first group, who went infrequently into the new cave). The bottom of the cave reaches the lukewarm-water level: there is the Tavas-terem (Lake Chamber). There are white popcorns everywhere on the walls, often with $2-3 \mathrm{~cm}$ long fragile semi-transparent aragonite crystal needles. The popcorns create logomite and logotite pillars too. We can find white wet powder, hydromagnesite, and huntite on the precipitations. It is a real crystal cave! There are $10-20 \mathrm{~cm}$ long stalactites hanging from the ceiling in the Dripstone Chamber, and the flowstones are also frequent here. There are a lot of beautiful corrosion pockets on the walls of the cave and 1-3 m diameter cupolas in the ceiling. This is a typical hydrothermal cave system with a labyrinth-type network of passages.

Interestingly, many palaeontological finds, mainly Pleistocene bones of small mammals were collected in the territory of the mine, mostly from the caves and the opened chasm (Jánossy 1986, 1992, Pazonyi et al, 2019). Now it is prohibited to hew the stone at least $50 \mathrm{~m}$ from the cave, but the mine and the cement plant can continue working, and the cave is protected.

\subsection{Nagyharsány}

There is a big limestone quarry (the rocks are also built up from Middle Cretaceous limestone) $5 \mathrm{~km}$ north from the Beremend Crystal Cave, at the western part of Szársomlyó Hill (the southern side of the $442 \mathrm{~m}$ high hill is free of loess sediment: it shows impressive bedding). This quarry also gives basic material for the Beremend cement plant. This hill is also very rich in Pleistocene Vertebrata fossils, which are known over the world (Kubinyi, 1854, Kordos, 1991). The hill is a little independent from the other parts of the Villány Mountains. The southern slopes of the Villány Mountains enjoy a strong Mediterranean influence, which is most favorable for the famous red wine produced here!

The cave opens at a lucky place of the quarry, at the southwestern edge of the nine. There is only an 8-10 m thick cap over the cave passages! The roots are hanging down from the ceiling. The $1500 \mathrm{~m}$ long and $64 \mathrm{~m}$ deep cave is on a 130 x $30 \mathrm{~m}$ area. The first few meters of the cave were discovered after an explosion in the spring of 1994. The leader of the mine asked for permission to mine this part of the mine together with the small cave. Two experts from the Nature Protection Office went to see the object, and they found the continuation of the first few meters (Takács-Bolner, 2003b). The passages of the cave follow the steep dipping (175/58) of the limestone. The temperature in the cave is around $14{ }^{\circ} \mathrm{C}$. The chasms are rich in beautiful cupolas and other solution forms. There is a big difference between the eastern part and the western part of the cave (Vigassy et al 2010).

The size of the passages in the eastern part of the cave is smaller than in the western part. Here are very big calcite veins: their width is $20-30 \mathrm{~cm}$, and the small prepared veins make a boxwork net. Many cupolas dissolved into the big old veins. On the soft walls, there are 1-2 cm thick solution residual deposits. It is an altered rock due to the hydrothermal effect. This part is richer in hydrothermal minerals than the western part. Here, the popcorns create stalagmite-like forms: $30-40 \mathrm{~cm}$ high logomites, which consist of pure popcorns, with the hole in the middle. Sometimes aragonite needles are also visible on the wall. The lower passages of the eastern part are thinner and full with half-meter-high thin stalagmites. It is difficult to move without destroying dripstones in narrow 
places. The passages did not reach the karstic water level, but there may be an air communication with the surroundings of the lukewarm karstic water because the temperature of the air is higher here.

The western part is wider and very rich in big $\left(100 \mathrm{~m}^{2}\right)$ flowstones and two generations of the 2-3 $\mathrm{m}$ high stalagmites. (There are some old, very much corroded, and some living samples). The surfaces of the stalagmites and the flowstones are covered by white-yellowish popcorns very often. The popcorns are usually on one side of the stalagmites only. Young dripstones can be observed on the popcorns too... In a place, very long, one to two-meter straw stalactites hang from the ceiling. There are many fossils of Pleistocene animals mainly bats and small rodents - in the Csontos (Bone) Chamber. Exploitation in this part of the mine is strictly prohibited: protecting this fantastic cave was a success!

\subsection{Hárskút Cave}

The 1,200 $\mathrm{m}$ long and $75 \mathrm{~m}$ deep dripstone cave opens in a limestone quarry in the northwestern part of Köris Hill (704 $\mathrm{m}$ ) in the Bakony Mountains. This big cave, which has a 70 $\mathrm{m}$ long, $10 \mathrm{~m}$ wide, and $30 \mathrm{~m}$ high chamber, was discovered from the known small cave in 2018. Beautiful, intact clay forms on the floor, big flowstones on the wall, and draught popcorn too. Now the responsible ministry of Hungary prohibited the work within 50 meters from the cave. As this mine is not big, it does not work these days.

\subsection{Tatabánya, Keselő Hill}

Keselő Hill, built up from Triassic limestone and dolomite, is at Tatabánya, $50 \mathrm{~km}$ northwest to Budapest, beside the M1 Highway between Budapest and Wien. There is a very big limestone quarry, which gives basic material for road construction. During the last decades, 26 independent caves were found in the mine. Many of them were annihilated by mining, though 15 survived until today. For example, the mine got permission to annihilate the $10 \mathrm{~m}$ long Keselö Hill No. 12 Cave 15 years ago, where there were some beautiful barite crystals and flowstones. (I wrote the expert opinion.)

The $600 \mathrm{~m}$ long and $115 \mathrm{~m}$ deep Keselő Hill Cave (Nyerges 2003) is in the southwestern corner of the mine, which is a very lucky place: it does not disturb the activity of the mine. It is a huge, 2-5 m wide chasm. Strong ladders were built down to $65 \mathrm{~m}$ from the surface, which make it very easy to study the beautiful precipitations: the huge, several $\mathrm{cm}$ sized white popcorns and the thick calcite veins. The bigger part of the chasm is covered by a $1-5 \mathrm{~cm}$ thick calcite crust.

The Keselő Hill No. 20 cave is also a very beautiful cave, very rich in popcorn. It opens at the deepest point of the mine. In 2020, the mine wanted to annihilate it, but the responsible ministry of Hungary prohibited it and protected this cave. However, this ministry permitted to annihilate 4 other small caves (the Keselö Hill No. 6, No. 7, No. 9, and No 26 Cave, all without any precipitation) last year, which hindered the expansion of the mine.

\subsection{Budapest, Rózsadomb}

Modern Budapest was developed in the second part of the 19th century. The buildings needed a large amount of basic material: stones and bricks. The brick was baked from Oligocene Kiscell Clay mined on the eastern part of Hármashatár Hill, which looks on the Danube. The Eocene Szépvölgy (nummulitic) Limestone is mined in the Pál Valley. Here several quarries were opened: Mátyás Hill Eastern Quarry, Mátyás Hill Western Quarry, Pál Valley Quarry, French Quarry, Fenyőgyöngye Quarry, Kecske Hill Quarry, etc. These hills are full of cave passages: at this moment, we know more than $60 \mathrm{~km}$ of cave passages, but I think there are more than $100 \mathrm{~km}$ cave passages - now half of them is unknown.

Nature protection was very lenient in the first part of the 19th century. These mines "ate" big pieces from the hill - together with the cave passages which were in the limestone. Therefore, at this moment, we know 16 small caves in the Mátyás Hill Eastern Quarry, 18 smaller-bigger caves in the Pál Valley Quarry, 6 small caves in the French Quarry, etc.

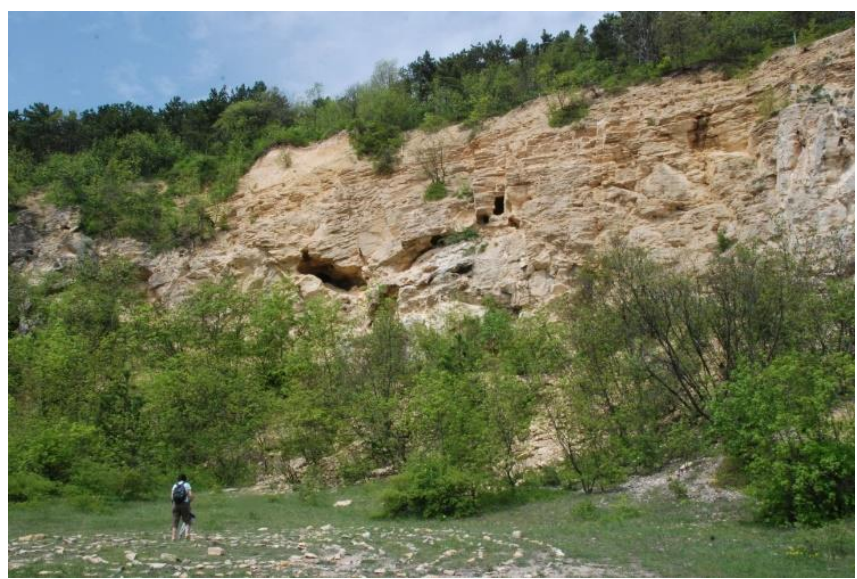

Figure 3. Old limestone quarry in Mátyáshegy with cave entrances. Photo: Szabolcs Leél-Össy

The entrance of the Pálvölgy Cave System (opened in 1904) is also in the Pál Valley Quarry - like the entrance of the Harcsaszájú (Mouth of Catfish, opened in 1902) and Hideglyuk (Cold Hole, opened in 1904). The entrance of Mátyáshegy Cave opens in the Mátyás Hill Western Quarry (opened around 1936). The cavers discovered the connection between Mátyáshegy Cave and Pálvölgy Cave in 2001, between Harcsaszájú Cave and Hideglyuk Cave in 2009, and between the two big systems in 2010. Now the Pálvölgy Cave System is the longest cave in Hungary: longer than $32 \mathrm{~km}$ !

The Szemlöhegy Cave (2.2 km long) was discovered also during mining in 1930, but it was a very small mine: the limestone was mined for the house. The other two big caves of Budapest were also opened artificially, not by quarrying (Ferenchegy Cave - $6.5 \mathrm{~km}$ long - during canalization in 1933; Józsefhegy Cave $-6.5 \mathrm{~km}$ long - during the digging of a house-base pit in 1984). Only the first section of the wet and active Molnár János Cave (6 km long) was discovered from 
the natural entrance (in 1976), behind the Lukács Spa. After opening the entrance of a new cave in the Rózsadomb area, we often have to dig down to 10-30 $\mathrm{m}$ to reach open passages.

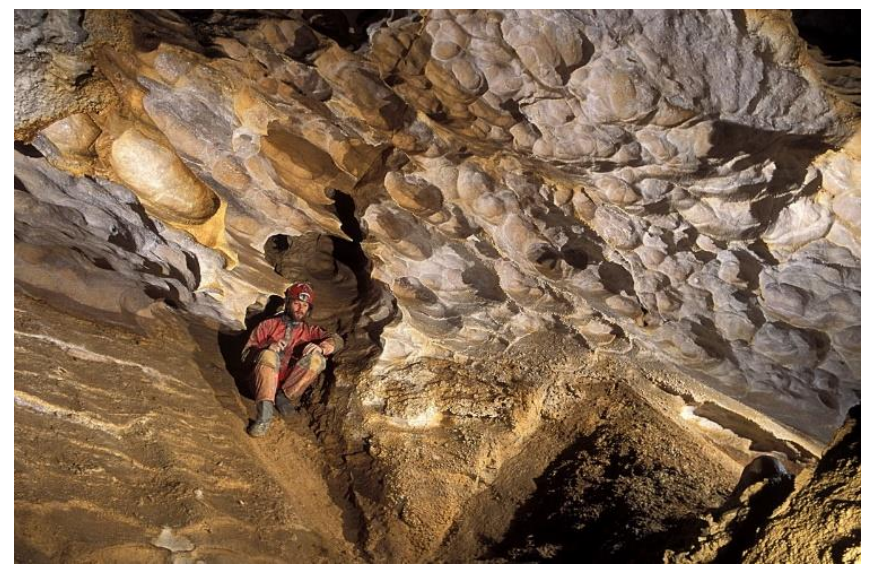

Figure 4. Corrosional pockets in Pálvölgy cave. Photo: Csaba Egri

(The same happened in the Józsefhegy Cave in 1984, where I was the leader of the explorers. Now we are doing research here again - we are looking for new passages). I worked at many house-building projects in the last 40 years, and we found with my colleagues three dozen new small caves. These caves are under the streets and the houses. In certain cases, the caves mean risk for the buildings or, on the other hand, the new buildings endanger conditions in the caves. Recently, there are rigorous rules to regulate building activity above the caves.

The caves of Budapest are typical hypogene (hydrothermal) caves, which were formed by ascending thermal water, by mixing corrosion. (This explains why all these caves were discovered in the last 120 years as consequences of different human activities) The thermal water causing dissolution in the caves of Rózsadomb is not of juvenile origin. It is part of a gravitationally driven large hierarchical regional groundwater flow system. Characteristic of these caves is the multi-level labyrinth-type network of passages, the striking of tectonic preformation, the narrow passages between the huge (20-30 m big) chambers (the largest chamber is the $67 \mathrm{~m}$ long Kinizsi Chamber in the Józsefhegy Cave), and the rich hydrothermal (carbonate and sulfate) mineral ensemble. All of them are independent of the surface processes (they were dissolved by rising lukewarm water), there are no fluviatile sediments in the passages, and they are rich in spherical cupolas and hemispherical solution pockets. The host rock of the caves here is mainly the Eocene Szépvölgy (nummulitic) Limestone. The upper passages sometimes dissolved in Eocene-Oligocene Buda Marl, and the lower part sometimes in Triassic well-bedded and cherty Mátyáshegy Limestone.

These more than 100 caves (altogether $60 \mathrm{~km}$ cave passages) are in an area of 5-6 km² around Rózsadomb (Rose Hill). The thermal springs which dissolved the caves are beside the Danube at this moment, at a level around $100 \mathrm{~m}$ lower than 500.000-1.000.000 years earlier, when the caves developed.
These springs are „feeding” the world-famous medical spas of Budapest (Gellért Spa, Rudas Spa, Lukács Spa, Széchenyi Spa, etc.).

These several $\mathrm{km}$ long caves are very interesting! A few hundred $\mathrm{m}$ long illuminated part of the Szemlöhegy Cave and Pálvölgy Cave is open for tourists. The Pulmonary Section of St. János Hospital follows breathing treatment for people with asthmatic diseases before and after touristic hours (every morning and afternoon) in the Szemlöhegy Cave. The most characteristic mineral in these caves is popcorn. They are yellow-brownish in the Ferenchegy and Szemlöhegy Caves, and white in the Józsefhegy Cave. The frequent matter of the precipitations is calcite: veins, subaqueous coatings, cave rafts, cave cones, pool fingers, angular botryoids, septaias, and folias are deposits of warm water. (Specialities are the two-meter high cave cones - the Hungarian name is the Christmas tree -, which are built up from cave rafts and covered by popcorns outside.) Calcite is also the matter of the popcorns (coralloids), glass-ball botryoids, draught botryoids, pool deposits, and dripstones precipitating by evaporation. (There are not many dripstones in these caves, because the beds, almost everywhere, are of the Buda Marl, which is rich in clay. Therefore the infiltrating water is mostly poor in carbonate and does not contain enough $\mathrm{HCO}_{3}{ }^{-}$to create big dripstones. Not too big, but beautiful stalactites and small stalagmites can only be found in the Pálvölgy Cave System and in the Józsefhegy Cave.

The most valuable crystals are the $2-3 \mathrm{~cm}$ long and semitransparent aragonite needles (frostworks), which are common in the Józsefhegy Cave, though occur in the Szemlöhegy Cave too. The Józsefhegy Cave and Szemlőhegy Cave are very rich in different gypsum crystals: chandeliers (the biggest ones are almost $1 \mathrm{~m}$ long!), crust, flowers, hair, needles. Other 30 minerals were identified in the Rózsadomb caves, for example, romanechite and hollandite coating (precipitated by microbial processes), moonmilk (hydromagnesite and huntite), „limonite”, pyrite, kaolinite, montmorillonite, zircon, quartz, pyroxene, granet, etc. (LeélÖssy and Surányi, 2011, Leél-Össy 2017) The most beautiful pieces can be seen in the Józsefhegy Cave, where taking a tour is prohibited, except for scientific research with special permission.

The wide passages of the active Molnár János Cave are filled up with lukewarm $\left(17-27^{\circ} \mathrm{C}\right)$ water in $98 \%$, and there are no precipitations. The first 20 meters are known from 1856. In 1976 , a $300 \mathrm{~m}$ passage was discovered, and we know the whole of the cave from 2001. It is open for diving tourists.

\subsection{Vác, Naszály Hill}

There is a large cement plant at the Danube at the foot of the $652 \mathrm{~m}$ high hill $30 \mathrm{~km}$ north of Budapest. A very big limestone quarry is operated on the hill, which is visible form from Budapest. We do not have data about the annihilated caves, but a big explosion in 2002 opened the 'Nincs kegyelem' (No Pardon) Cave, which is $225 \mathrm{~m}$ long and $70 \mathrm{~m}$ deep. In the cave, there are three 30-50 m deep shafts, and 
beautiful carbonate crystals. The cave passages are sometimes very close (5-65 $\mathrm{m}$ ) behind the open mine-ground. Therefore, the quarry removed the mining into another ground, and operation near the cave has been prohibited.

\subsection{Esztrámos (near to Aggtelek)}

The mine worked on the top of this hill for half a century. Quarrying annihilated many small caves, which were veryvery rich in different calcite crystals. I have eye-witnessed when a beautiful cave chamber was annihilated in 1975. Only the $410 \mathrm{~m}$ long Földváry Cave was saved on the top. A special method was used here: an $8 \mathrm{~m}$ wide shaft was drilled in the middle of the hill, and the mined limestone dropped into the shaft. A horizontal adit was made at the foot of the hill to bring the limestone to the surface. During building the adit, two fantastic caves were discovered: the Rákóczi No. 1 and Rákóczi No. 2 Caves. They reach the level of the lukewarm karst water, and they are very-very rich in calcite precipitations, mainly in popcorns and dripstones (Kraus 2003). The Rákóczi No 1 Cave is one of the most beautiful caves of Hungary!

There was an iron-ore mine here 100 years ago. The firm built a 7-level mining system and found some small, but very spectacular caves. Limestone mining stopped here 20 years ago: the known (and unknown) caves are protected.

\section{REFERENCES}

Csondor, K. (2021) Hydrogeological investigation of Villány Thermal Karst. PhD Thesis (in Hungarian). Budapest: Eötvös Loránd University.

Ford, D. C. and Williams, P. (2007) Karst Geomorphology and Hydrology. Wiley J West Sussex p 563.

Hill, C. A. and Forti, P. (1997) Cave minerals. Huntsville, Alabama, USA p 463

Jánossy, D. (1986) Pleistocene vertebrata faunas of Hungary. Budapest-Amsterdam: Akadémiai Kiadó et Elsevier, p 208.

Jánossy, D. (1992) Lower Pleistocene Bord Remains from Beremend (S-Hungary, Lopc. 15. and 16.) Aquila, 99 9-25

Kordos, L. (1991) 'Villány Mountains, Csarnóta, Pliocene palaeovertebrata localities' (in Hungarian). In Magyarország Geológiai Alapszelvényei, Budapest: MÁFI, 148:6.
Kraus, S. (2003) 'Rákóczi No. 1. Cave)' (in Hungarian). In Székely, K. (ed) Highly protected caves of Hungary. Budapest, Mezőgazda, pp 315-317.

Kubinyi, F. (1854) 'The limestone of Beremend and the bones in the limestone' (in Hungarian). In Magyar és Erdélyország képekben, II: 56-58.

Leél-Őssy, Sz., Szanyi Gy. and Surányi, G.. (2011) 'Minerals and speleothems of the Józsefhegy Cave (Budapest, Hungary)', International Journal of Speleology 40(2): 191203.

DOI: $\underline{10.5038 / 1827-806 X .40 .2 .11}$

Leél-Össy, Sz. (2017) 'Caves of Buda Thermal Karst', in Klimchouk, A., N. Palmer, A., De Waele, J., Auler, A.S., Audra, P. (eds.) Hypogene Karst Regions and Caves of the World). Cham, Switzerland: Springer, pp. 279-298.

Leél-Össy, Sz. (2021) 'The caves of the Villány Mountains', in Veress, M. and Leél-Össy, Sz. (eds) Karsts and Caves of Hungary. Cham, Switzerland: Springer (in press)

Leél-Össy, Sz. and Virág, M. (2021) 'The Caves of the Northeastern Part of the Transdanubian Mountains', in Veress, M. and Leél-Össy, Sz. (eds): Karsts and Caves of Hungary. Cham, Switzerland: Springer (in press)

Nyerges, A. (2003) 'The Cave of Keselő Hill' (in Hungarian), in Székely, K. (ed) Highly protected caves of Hungary. Budapest: Mezőgazda, pp 315-317.

Pazonyi, P. et al. (2019) Preliminary report on the Early Pleistocene vertebrate sites of Beremend Crystal Cave (Beremend 16, South Hungary) and on their palaeoecological importance. Fragmenta Palaeontologica Hungary C. A.

Takácsné-Bolner, K. (1981) 'New discoveries in Pál-völgy Cave' (in Hungarian). Karszt és Barlang 1980: 87-92.

Takácsné-Bolner, K. (2003a) 'Beremend Crystal Cave' (in Hungarian), in Székely, K. (ed) Highly protected caves of Hungary. Budapest: Mezőgazda, pp 399-403.

Takácsné Bolner, K. (2003b) 'Nagyharsány Crystal Cave' (in Hungarian), in Székely, K. (ed) Highly protected caves of Hungary. Budapest: Mezőgazda, pp 404-406.

Vigassy., T, Leél-Össy, Sz., and Demény, A. (2010) 'Genetic investigations on the precipitations of the Beremend and Nagyharsány Caves' (in Hungarian), Földtani Közlöny 140(1): 7385 .

(C) 2021 by the author(s). This article is an open access article distributed under the terms and conditions of the Creative Commons Attribution (CC BY) license (http://creativecommons.org/licenses/by/4.0/). 